\title{
Australia's Financial \\ Ombudsman Service: An \\ Analysis of its Role in the \\ Resolution of Financial \\ Hardship Disputes
}

\section{Paul Ali}

\section{Evgenia Bourova}

\section{Joseph Horbec}

\section{lan Ramsay}

The Financial Ombudsman Service (FOS) was established in 2008 to resolve disputes between Australian consumers and financial service providers. This article outlines the role of FOS in resolving disputes under the statutory protections for Australians in financial hardship. This article also sets out the results of a study of data collected by FOS in relation to financial hardship disputes resolved between 2010 and 2014. This data highlights the importance of FOS in a context where most disputes are resolved outside the courts, particularly in the aftermath of the global financial crisis, when the number of financial hardship disputes rose significantly.

This research is supported under the Australian Research Council's Discovery Projects funding scheme (project number DP140101031). We are grateful to FOS for supporting this research and providing us with the data that forms the subject of this article. We also gratefully acknowledge the comments made by the three anonymous reviewers on earlier drafts of this article.

Since 2009, Australia has had a national set of protections for consumers in financial hardship, defined as where a person is willing, but unable, to meet their debt obligations when they fall due. These protections are centered on section 72 of the National Credit Code, which is scheduled to the National Consumer Credit Protection (NCCP) Act 2009 (Commonwealth of Australia 2009). Section 72 allows consumers in financial hardship to apply to their credit provider for a variation of their credit contract, and requires credit providers to respond to such an application within prescribed timeframes.

This is the author manuscript accepted for publication and has undergone full peer review but has not been through the copyediting, typesetting, pagination and proofreading process, which may lead to differences between this version and the Version of Record. Please cite this article as doi: $10.1002 /$ crq. 21187 
Disputes in relation to this provision can arise for a variety of reasons; for example, the credit provider may not respond to the application, or may refuse to vary the contract, or may not suspend enforcement proceedings against the consumer. Usually, the first step for the consumer in these situations is to initiate the credit provider's own internal dispute resolution process by making a complaint to their complaints officer, either over the phone or in writing, and awaiting a response. If the dispute is not resolved internally, the primary forums to which the consumer may make a complaint against the credit provider are the two independent external dispute resolution (EDR) schemes provided by the Financial Ombudsman Service (FOS) and the Credit and - Investments Ombudsman (CIO). Most Australian banks are members of FOS, while many credit societies and credit unions are members of CIO. These schemes - together with other industry-funded ombudsman services established in the Australian telecommunication, energy, and water sectors-have the aim of providing an accessible avenue for the resolution of consumer disputes with a minimum of formality and technicality (see, e.g., FOS 2010c, clause 1.2). While these schemes focus primarily on alternative dispute resolution methods such as negotiation and conciliation, Rhoda James and Philip Morris (2003, 168) suggest that in this context, the term "alternative dispute resolution" is something of a misnomer: for consumers in financial hardship seeking to make a complaint against their credit provider, the free-of-charge service provided by an industry-funded ombudsman is usually "the only viable means of redress, not so much an alternative to the courts."

In this article, we examine the role played by FOS in the resolution of financial hardship disputes - referred to by FOS as "financial difficulty disputes"- the majority of which arise under the National Credit Code. FOS is a company limited by guarantee that was established on July 1, 2008 to resolve disputes between financial service providers (FSPs) and consumers (and qualifying small businesses). It is funded by membership and dispute resolution fees paid by its member FSPs. Annual reviews published by FOS between 2008-09 and 2013-14 reveal that from when it first commenced operations until July 2014, FOS has received approximately 176,550 disputes (FOS 2010b, 2011, 2012, 2013a, 2014). Of these, between 17 and 19 percent comprised financial difficulty disputes. Other types of disputes resolved by FOS include disputes in relation to advice provided by an FSP; fees and charges; disclosure of information about a product or service provided by an FSP; denial of a claim; or a failure to follow instructions (FOS 2014). In addition to its role as an EDR service, FOS also has a role in administering the major codes of practice developed by Australia's banking, insurance, and customer-owned banking sectors (e.g., the Australian Bankers' Association's [2013] Code of Banking Practice). 
In the following section of this article, we summarize the history of FOS since its establishment in 2008, and provide an overview of its role under the legal frameworks covering the Australian financial services sector. We also outline the process that has been used by FOS to resolve financial difficulty disputes for much of its period of operation. Next, we undertake an analysis of data collected by FOS in its case management system in relation to financial difficulty disputes resolved between January 1, 2010 and December 31, 2014.

-This data is not publicly available. It therefore provides scholars and others working in the field of conflict resolution in Australia and in other jurisdictions with a rare glimpse of what dispute resolution by an industry-funded

- ombudsman service can involve. In particular, this data illustrates the importance of agreements between applicants and FSPs, as opposed to final determinations by the ombudsman, in resolving the vast majority of disputes received by such services (see also, O'Shea 2006). This data also highlights the importance of promoting community awareness of such services, as the majority of applicants to FOS are not referred by a professional such as a financial counselor, and most consumers in financial hardship do not obtain any professional advice or assistance (Schetzer 2008).

Our findings have a number of policy implications, particularly for the Australian financial services sector. First, they indicate that some FSPs are still not complying with the requirement to respond to a request for hardship assistance in section 72 of the National Credit Code. While the gradual increase in the number of financial difficulty applications involving a failure to respond by the FSP could also be attributed to greater consumer awareness of FOS, only a minority of consumer complaints are escalated to EDR, suggesting that the actual number of requests that receive no response from the FSP is much higher. Secondly, our findings demonstrate the importance that FOS has acquired in its relatively short period of operation, particularly amid the significant increases in the number of applications relating to financial difficulty in the aftermath of the global financial crisis. Given that FOS is one of the primary forums through which Australian consumers can seek redress from their credit providers, this in turn highlights the need for further investigation of the extent to which FOS - and EDR services in other jurisdictions - succeed in providing consumers in financial hardship with an accessible process for making a complaint against their FSP, and delivering outcomes that assist them in meeting their financial obligations. 


\section{A History of FOS}

As documented by Shahla Ali (2013), the use of ombudsman services as an alternative to the courts has been a part of the Australian legal system since the 1970s. The first such services were publicly funded bodies such as the Commonwealth Ombudsman, established to investigate complaints in relation to the decisions of a government department or agency. More recently established are industry-funded ombudsman schemes, which did not begin to emerge in Australia until the late 1980s and early 1990s. In this section of the

= article, we set out a history of FOS and outline its role in the context of financial hardship dispute resolution in Australia.

Calls for the establishment of a free and independent ombudsman scheme for the financial services sector in Australia began around the late 1980s. These calls came in the context of an increasing volume of consumer complaints to banks (Banking and Financial Services Ombudsman Limited 2004, 16; Bolkus 1989). Also influential was the rise in competition in the newly deregulated financial services sector, and an increasing policy emphasis on self-regulation (Banking and Financial Services Ombudsman Limited 2004). The first industry-funded ombudsman scheme to be established in Australia was the Banking and Financial Services Ombudsman (BFSO), which commenced operations in 1990. Modelled on the example of the Banking Ombudsman in the United Kingdom, the BFSO provided its dispute resolution service free of charge to consumers and small businesses, and was funded by fees paid by members. By the late 1990s, there were seven EDR schemes covering the financial services sector alone (Ali 2013). Some of these schemes, such as the Insurance Ombudsman Service Limited and the Credit Union Dispute Resolution Centre, had a membership confined to a particular type of FSP, while others - for example, the BFSO - dealt with complaints against a broad range of FSPs, including stockbrokers, fund managers, and advisers (Pearson 2009).

In Australia, ombudsman schemes such as these have been described as "a mandatory system of access to justice in the consumer marketplace" (Malbon 2012, 345). In 1994, the Access to Justice Advisory Committee chaired by Ronald Sackville QC — which was appointed to make recommendations for reforms to the administration of the Commonwealth justice system - defined "access to justice" as requiring equality of access for all consumers to "effective dispute resolution mechanisms necessary to protect their rights and interests"; and equality before the law, "regardless of race, ethnic origins, gender or disability" (Access to Justice Advisory Committee 
1994, 7-10). As Justin Malbon (2012) notes, the rationale for EDR schemes funded by industry centered upon the perception that improved access to justice for consumers would also have benefits for FSPs, in the form of increased "consumer trust" and "consumer participation in the market":

Because firms benefit from improved access to justice, it can be reasoned that they should bear some of the cost of providing access, which admittedly is passed on to consumers through the increased cost of goods and services. (330)

In 1997, the final report of the Commonwealth Government's Wallis Inquiry into the Australian financial system (Wallis Report) highlighted the " existence of "gaps, overlaps and inconsistencies" (287) between the EDR schemes covering the financial services sector. The Wallis Report attempted to deal with these gaps by recommending the establishment of a central complaint referral service for all consumers of financial services, but stopped short of calling for the schemes themselves to be amalgamated (Commonwealth of Australia 1997, 287-88). In 2000, the Australian Securities and Investments Commission (ASIC 2000) made its own qualified call for rationalization:

Sensible rationalisation will help to drive down overall costs for industry, improve scheme standards, facilitate the consistent treatment of similar products and services, reduce consumer confusion, and reduce regulator costs. (49)

Yet the perceived disadvantages of such a proliferation of EDR schemes could not be resolved entirely by initiatives for greater cooperation between these schemes (Pearson 2009). Those disadvantages included confusion regarding which body had jurisdiction over a dispute and on which basis the dispute would be determined, as well as consequent time delays and costs (Trigg 2006). On August 2, 2007, Chris Pearce, the Parliamentary Secretary to the Commonwealth Treasurer, endorsed recommendations for the merger of the three largest EDR schemes in the financial services sector, including the BFSO, into a single scheme. ASIC approved the proposed merger on May 20, 2008, and FOS came into operation on July 1, 2008. Two more schemes-the Credit Union Dispute Resolution Centre and the Insurance Brokers Disputes Limited - also merged to become part of FOS on January 1, 2009.

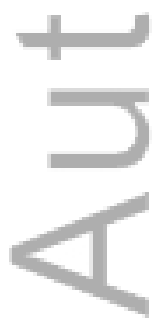




\section{The Role of FOS under the Relevant Legal Frameworks}

Before we focus specifically on the role of FOS in the context of financial hardship dispute resolution, it is useful to examine the legislative frameworks underpinning its role in the broader context of providing EDR services to consumers of financial services. In Australia, these frameworks center upon two pieces of Commonwealth legislation: the Corporations Act

= 2001 (Corporations Act) and the NCCP Act (Commonwealth of Australia 2001, 2009). Under section 911A of the Corporations Act and section 29 of the NCCP Act, a person who carries on a financial services business or engages in credit activities is required to hold a license issued by ASIC. Section $912 \mathrm{~A}(2)(\mathrm{b})$ of the Corporations Act requires Australian financial service license holders to be members of an ASIC-approved EDR scheme covering complaints made by retail clients in connection with all services covered by the license. A similar requirement is contained in section 47(1)(i) of the NCCP Act. Section 912A(2)(a) of the Corporations Act and section 47(1)(h) of the NCCP Act also require license holders to have in place an internal dispute resolution procedure that complies with the standards and requirements made or approved by ASIC. The only two ASIC-approved EDR schemes for credit providers are those provided by FOS and CIO.

Under clause 4.2 of its Terms of Reference, which came into effect on January 1, 2010, FOS has jurisdiction to consider disputes relating to credit, payment systems, deposit taking, insurance, investments, and superannuation, as long as they are brought against an FSP that is a member of FOS at the time of the registration of the dispute. Clause 5.1(o) of the Terms of Reference limits the value of a claim that can be brought to FOS to $\$ A U D 500,000$. The FOS Terms of Reference also play the crucial role of providing for the independence of FOS from the industry that is its source of funding, by restricting the powers of its members to influence the decision-making process (Griffiths and Mitchell 2012, 130).

The role of FOS is not limited to the resolution of individual disputes. FOS is also required to identify systemic issues - defined as issues "that have implications beyond the immediate actions and rights of the parties to the complaint or dispute" (ASIC 2013, 139.119) — arising from a pattern of individual consumer complaints or disputes (ASIC 2013, 139.127). FOS must refer these issues to the relevant FSP for remedial action, and continue to monitor the matter until a resolution has been achieved (FOS 2010c, clause 
11.2). FOS is also required to report systemic issues - as well as serious misconduct - to ASIC (although it does not need to identify the FSPs involved; ASIC 2013, 139.127; Waye and Morabito 2012).

Our article, however, is concerned with the role of FOS in resolving financial difficulty disputes under the financial hardship provisions of the National Credit Code. Section 72 of the National Credit Code gives consumers in financial hardship the right to give their credit provider notice (known as a "hardship notice") that they may not be able to meet their obligations under a credit contract. This is referred to by FOS as a "financial difficulty request," as what the consumer is seeking is both a temporary reprieve from enforcement proceedings while the application is being considered and "assistance" in the form of a variation to their contractual arrangements (for example, a moratorium on repayments, or a temporary reduction in repayment amounts combined with an extension in the term of their loan). Sections 72 and 89A(1) require the credit provider to respond to the financial difficulty request before they can commence enforcement proceedings against the consumer. If the credit provider refuses to grant a variation, they must notify the consumer of the name and contact details of the EDR scheme of which they are a member, and outline the consumer's rights under that scheme. Section 74(1) of the National Credit Code provides the consumer with the right to seek a hardship variation in the courts. However, the very small number of cases testing that provision indicates that it is FOS and CIO, and not the courts, that provide the primary forum for the resolution of disputes under section 72 that are taken beyond the internal dispute resolution process of the credit provider.

\section{The FOS Process for Resolving Financial Difficulty Disputes}

As stated in the introduction to this article, our data on financial difficulty disputes covers the period between January 1, 2010 and December 31, 2014. The FOS (2010c) Terms of Reference set out the three-stage process that was used by FOS to resolve financial difficulty disputes during this period. The first stage commences when an applicant first lodges a dispute with FOS, at which point FOS refers the dispute back to the FSP and requests that the FSP respond within 45 days (or 21 days if the applicant's complaint has already gone through the FSP's internal dispute resolution process). The parties may make an attempt to resolve the matter during this period by negotiating with one another with a view to agreeing on a course of action. Negotiation is the 
least formal means of alternative dispute resolution methods, and can take the form of written communications or telephone conversations, either directly between the parties, or through their legal advisors or agents (Sourdin 2012).

Not until the second stage does FOS undertake an assessment of whether the dispute falls within its Terms of Reference (meaning that it has jurisdiction to consider the dispute). The dispute is allocated to a case worker who assists the parties to resolve their dispute by agreement using negotiation or conciliation techniques. Negotiation, at this stage of the FOS dispute resolution process, involves the case worker contacting both parties individually to provide them with information about the range of possible

" outcomes if the dispute proceeds to a formal decision, after which it is up to the parties to reach an informed agreement on a course of action. Conciliation is a more structured process (Sourdin 2012). The definition of conciliation endorsed by Australia's National Alternative Dispute Resolution Advisory Council (NADRAC), and incorporated into the Australian Standard AS 46082004: Dispute Management Systems, is:

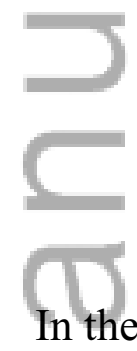

a process in which the parties to a dispute, with the assistance of a dispute resolution practitioner (the conciliator), identify the issues in dispute, develop options, consider alternatives and endeavour to reach an agreement. The conciliator may have an advisory role on the content of the dispute or the outcome of its resolution, but not a determinative role. (NADRAC 2003, 5)

In the context of FOS dispute resolution, conciliation usually involves a telephone conference between the consumer and a representative of the FSP, which is facilitated by professional mediator known as a conciliator (FOS 2015a).

If the dispute is not resolved by agreement during the second stage, then it proceeds to the third stage, which entails the highest degree of involvement by FOS. After giving the parties an opportunity to make submissions and provide information about the matter in dispute, FOS can make an assessment known as a "recommendation," either in writing or over the phone. If, within 30 days, the FSP does not accept the recommendation - or either party requests that the dispute proceed to the next stage - then the dispute proceeds to a "determination" by an ombudsman or by a panel of three decision makers chaired by an ombudsman. A determination can be distinguished from a court decision in that it is binding on the FSP, but not on the applicant. A recent series of publications by FOS titled The FOS Approach - Financial Difficulty Series $(2013 b, 2013 \mathrm{c})$ stipulates that a recommendation or a determination must reach a conclusion about the merits of the dispute-including whether the FSP has responded appropriately by giving genuine consideration to the 
applicant's financial difficulty - and specify any remedy that FOS considers fair and appropriate. In the context of financial difficulty disputes, the most relevant remedy is the variation of the terms of a credit contract on the grounds of hardship.

Unlike a court, FOS is not bound by any legal rule of evidence, and is not required to follow precedent (FOS 2010c, clauses 8.1, 8.2). When deciding a financial difficulty dispute, FOS will have regard to the principles contained in the National Credit Code and the applicable industry codes of practice, including the broad commitment to assist or work with consumers experiencing payment difficulties under a credit contract contained in codes such as the

" Australian Bankers' Association's Code of Banking Practice (2013, clause 28.2) or the Customer Owned Banking Association's Customer Owned Banking Code of Practice (2014, clause 24.1). The key consideration is whether the applicant can "demonstrate an ability to service the loan in the future": as the FOS (2013c) publication "Our Power to Vary Regulated Contracts" makes clear, a variation will only be granted in circumstances where this would see the repayment of the loan in full within a reasonable period. Denis Nelthorpe and Kate Digney $(2011,18)$ argue that this approach effectively excludes consumers whose financial problems are long-term or entrenched, with industry EDR schemes tending to require that the consumer be able to discharge their obligations within a fairly short-term period, usually a matter of months.

If FOS is satisfied that the FSP has genuinely considered the applicant's financial difficulty, and the applicant's financial difficulties are such that they cannot be overcome, the FOS approach is that the FSP should provide "a reasonable timeframe" for the applicant to pay off their debt and potentially to "voluntarily surrender assets which secure the loan or refinance their debts" (FOS 2013c, 3). If, on the other hand, the FSP is found to have failed to give genuine consideration to the applicant's financial difficulty, FOS may order them to pay compensation - for example, for enforcement costs, default charges, and fees - to the applicant in addition to ordering a variation of the credit contract.

Since July 1, 2015, FOS has had a new approach to resolving financial difficulty disputes, one that involves more active engagement by FOS from the very beginning of the dispute (FOS 2015b). This approach was developed partially in response to recommendations made by the first independent review of FOS by CameronRalph Navigator in 2013. The review found that FOS was meeting all of the ASIC benchmarks for industry-based EDR schemes apart from efficiency. The review identified a need to reduce delays in the dispute resolution process, recommending measures such as the introduction of a fast- 
track process for simpler, lower-value disputes (CameronRalph Navigator 2014), and generally prescribing "a more assertive approach that produces more timely resolution" (59). The new process prescribes a period of just 21 days between the date when a financial difficulty dispute is registered with FOS and when FOS will commence investigation if the dispute is not resolved between the applicant and the FSP. It also entails involvement of an FOS case manager at an earlier stage. It is hoped that these changes will address some of the particular problems associated with delays in the resolution of financial difficulty disputes - such as allowing interest to accrue on debt that is the subject of dispute, extending the period of hardship for the consumer, and increasing the likelihood that the applicant will drop out of the process and potentially accept an unfavorable offer from their FSP (for more detail on these problems, see the submission to the independent review of FOS by the Consumer Credit Legal Centre [New South Wales] and the Consumer Action Law Centre, 2013).

\section{Insights into FOS Financial Difficulty Dispute Resolution: An Analysis of Data from 2010 to 2014}

Financial difficulty disputes comprise only a minority of all disputes resolved by FOS. However, in this article, we focus specifically on financial difficulty disputes, as it is in the area of financial difficulty that the availability of an informal and free of charge dispute resolution service such as FOS becomes particularly important. The majority of people making an application to FOS or CIO under the hardship provisions in the National Credit Code would not be able to access dispute resolution through other means. Yet questions have been raised about the extent to which dispute resolution through FOS is accessible for particularly disadvantaged consumers. For these reasons, the role of FOS in the context of financial difficulty is deserving of a particular focus at a time when financial hardship remains the subject of concern both in -Australia and in other jurisdictions.

Both the overall number of disputes received and accepted by FOS and the number of disputes that were about financial difficulty have varied significantly from year to year. This variation in the caseload of FOS is shown in Table 1, which is based on figures in annual reviews published by FOS, and uses estimates - see the bolded figures in the columns titled "Received 
Financial Difficulty Disputes" and "Received vs Total" for the year 2009-to account for changes in the FOS reporting system between 2009 and 2010. As shown in Table 1, in 2008-09 FOS received a total of 22,392 disputes, of which 18 percent (or approximately 4,031 disputes) were financial difficulty disputes. In 2009-10, this number went up to 23,790 disputes, of which 11 percent (or 2,648 disputes) were in relation to financial difficulty. The number of financial difficulty disputes rose significantly in 2010-11, making up 20 pereent (or 6,102 disputes) out of a total of 30,283 disputes received. The following year, the total number of disputes received by FOS reached a peak of 36,099, of which 24 percent (or 8,659 disputes) were financial difficulty = disputes. Since 2012, the number of disputes received by FOS has gradually declined, reaching 31,680 in 2013-14, of which 19 percent (or 4,705 disputes) were financial difficulty disputes. In its annual reviews, FOS has suggested that this decline was caused by FSPs investing in improved processes for managing requests for hardship assistance, combined with an overall reduction in the number of consumers who requested hardship assistance in the first place, perhaps as a result of lower interest rates (FOS 2013a, 2014). Together, all of these figures evidence the importance that FOS has acquired as one of the primary forums for the resolution of disputes between people in financial hardship and their credit providers.

Insert Table 1 around here

Table 1, together with Figure 1, allows us to compare the total number of all disputes received by FOS with the number of financial difficulty disputes received, and also with the number of financial difficulty disputes that are actually accepted for dispute resolution. The italicized numbers and percentages of accepted disputes for the years between 2009 and 2011 in Table 1 are also estimates, as at that time, FOS was reporting the total number of disputes received each year, and not the smaller number that was actually accepted for dispute resolution. As can be seen, the gap between the number of financial difficulty disputes that were accepted and received has gradually decreased; in 2014, nearly 80 percent of financial difficulty disputes received by FOS were accepted for dispute resolution.

Figure 1. Comparing Total Number of Disputes Received with the Number of Financial Difficulty Disputes

Insert Figure 1 around here

The significant increases in financial difficulty disputes received and accepted between 2010 and 2012 - which are illustrated in Figure 1-have 
been attributed by FOS to the fallout from the global financial crisis of late 2007 and 2008, which "weakened the financial position of many consumers" at that time (FOS 2010b, 42). Increasing consumer awareness of FOS was also identified as a possible contributing factor (FOS 2012). These figures evidence the important role that FOS is playing in providing consumers affected by financial hardship with an opportunity to exercise the right contained in section 72 of the National Credit Code, even where their credit provider has not been -receptive to their request for an alternative payment arrangement. It is therefore surprising that there have not been more attempts to conduct a detailed analysis of what actually happens when these disputes go through the FOS process. The - only example of such an attempt was the independent review of FOS in 2013, which included a review of around 300 dispute files and telephone interviews with around 50 previous applicants (CameronRalph Navigator 2014). The review noted the difficulties of making any broad conclusions about the extent to which the FOS process is delivering outcomes that assist applicants to improve their financial position and meet their financial obligations (as opposed to, for example, facilitating arrangements with FSPs that are unaffordable for the consumer and that lead to a future default).

Given the clear need for empirical research into the role played by FOS in resolving financial difficulty disputes, we approached FOS to provide us with the data collected in its case management system in respect of the 21,501 financial difficulty disputes that were resolved by FOS between January 1, 2010 and December 31, 2014. In the following section of this article, we outline the findings of our analysis of this data, focusing first on the issues and products that the disputes were about, and then looking at the outcomes that the FOS dispute resolution process delivered for applicants over the five-year study period. Finally, we examine the information that FOS has made available in relation to the applicants who are using FOS to resolve these types of disputes.

\section{Issues, Products, and Types of FSPs Involved in FOS Financial Difficulty Disputes}

The findings in this subsection of the article provide insight into what the financial difficulty disputes resolved by FOS are about. When analyzed over time, these findings suggest possible changes in hardship practice by FSPs, and highlight the types of problems that can arise between consumers and FSPs when the former attempt to exercise their right to seek a variation of their credit contract on the grounds of hardship. Throughout this subsection, we refer to categories that are used by FOS to classify disputes, which are listed in the FOS (2014) Annual Review 2013-14. 


\section{Issue Types}

Financial difficulty is only one of several issue categories used by FOS to classify disputes, and incorporates a number of issues. The most common issue involved in financial difficulty disputes is an FSP's decline of a financial difficulty request, where the applicant makes a hardship application under section 72 , but the FSP refuses to vary the contract. This issue was involved in 43 percent of financial difficulty disputes between 2010 and 2014. The second most common issue is an FSP's failure to respond to a request for assistance, where the FSP does not respond to a hardship application under section 72 in - accordance with the prescribed timeframes. Falling into this category are 28 percent of disputes over the same period, followed by 25 percent of disputes that involve a request to suspend enforcement proceedings that are already in motion. Other issues - such as a default notice given to the consumer by the FSP, or an applicant rejecting a decision by the FSP - are less common, making up approximately 4 percent of the total number of disputes during the five-year period.

As shown in Figure 2, some of these issues have fluctuated more than others between 2010 and 2014, simultaneously suggesting changes in hardship practice by FSPs and lingering problems with compliance. The most significant changes took place in respect of disputes involving the decline of a financial difficulty request by the FSP, which reached a peak of 3,000 per annum in 2012 , before declining sharply to under 2,000 in 2013, and rising slightly in 2014. The improvement that took place in 2013 could be attributed to what FOS has described as "a greater willingness of FSPs to provide financial difficulty assistance if it is requested" (FOS 2014, 79). Yet disputes involving an FSP's failure to respond to a request for assistance have generally increased over the study period, and, to a lesser extent, so have disputes relating to a default notice. The continued prevalence of disputes involving a failure to respond by the FSP is particularly concerning, as it indicates a lack of compliance with the substance of the obligation imposed by section 72 of the National Credit Code. As for other issue types, disputes involving a request to suspend enforcement proceedings peaked at nearly 2,000 in 2012 but have been in decline ever since. Disputes where the applicant rejected the FSP's decision have not been recorded since 2011 .

Figure 2. Issue Types

Insert Figure 2 around here 


\section{Product Types}

The next category used by FOS to classify disputes concerns the types of financial products that are the subject of dispute. The vast majority - 91 percent — of financial difficulty disputes during our study period concerned consumer credit. Consumer credit products include credit cards, hire purchase and consumer leases, home loans, personal loans, short-term loans, and investment property loans - in short, the types of financial products that are regulated by the National Credit Code. As shown in Figure 3, the proportion of disputes involving these types of products peaked at 93.5 percent of financial - difficulty disputes in 2010 but declined to 88 percent in 2014. Figure 3 also shows a steady increase in disputes relating to business finance products, which are also a subcategory of credit that is not regulated by the National Credit Code, and which made up 8 percent of disputes during the entire study period (FOS 2010a). Business finance products include business credit cards, business loans, hire purchases, and lines of credit or overdrafts. In 2010, only 5 percent of all financial difficulty disputes were in relation to business finance products, rising to 10.5 percent in 2015 .

\section{Figure 3. Products}

Insert Figure 3 around here

Over our five-year study period, there have been fewer credit card disputes relative to other products, with the proportion of disputes that were in relation to credit cards decreasing from 37 percent to 25 percent of all disputes between 2010 and 2014. Meanwhile, home loan disputes rose from 35 percent in 2010 to 44 percent in 2012 before dropping back to 37.5 percent in 2014. Disputes in relation to business loans, hire purchase and consumer leases, lines of credit, and investment property loans have all increased over the study period, from a collective total of around 9 percent in 2010 to approximately 19 percent in 2014.

\section{Sales and Service Channels}

The next category used by FOS to classify disputes is "sales and service channels"- -being the types of business conducted by the FSP providing the product that was the subject of dispute. Banks are the type of business that is most likely to be the subject of a financial difficulty application to FOS, making up 73 percent of sales and service channels for financial difficulty disputes for all products (including business finance products) from 2010 to 
2014. Credit providers are responsible for 17 percent of applications, and debt collectors or buyers for another 5 percent.

\section{Outcomes of FOS Financial Difficulty Disputes}

The findings in this subsection of the article concern the outcomes of financial difficulty disputes closed by FOS between 2010 and 2014. The outcomes used by FOS to classify disputes are listed in annual reviews published by FOS (for example, FOS 2014) and correspond to the stage of the dispute resolution process at which FOS finishes handling the dispute. The data shown in Table 2 shows that the most common outcome in financial difficulty disputes is resolution by the FSP, which applies where the dispute proceeds no further than the first stage of the dispute resolution process outlined earlier in this article. Resolution by the FSP can include disputes where after communicating directly with the applicant, the FSP agrees to vary the contract or to pay monetary compensation to the applicant; or where the contract is voided or cancelled. This outcome also captures disputes where the FSP took no action, or where the precise result of the communications between the FSP and the applicant was not disclosed to FOS. More than 50 percent of financial difficulty disputes during the study period were resolved by the FSP. A further 20 percent of disputes were resolved at the second stage of the dispute resolution process, of which 12 percent were resolved through negotiation and 8 percent through conciliation.

The next most common outcome-making up 19 percent of disputes resolved during the study period - was where the dispute was assessed as being outside the FOS Terms of Reference. In its 2013-14 annual review, FOS explained that most of these disputes were excluded because they concerned debt recovery proceedings that had progressed beyond the point when FOS was able to consider the dispute (FOS 2014). Another 6 percent of disputes were discontinued by the applicant, either because the applicant notified FOS of their intention to discontinue the dispute, or because they stopped responding to communications from FOS. Only a very small proportion of disputes- just 2 percent - proceeded to the third stage of the dispute resolution process to be resolved through a decision by FOS, whether in favor of the applicant or the FSP. It should be noted that the independent review of FOS in 2013 expressed concern that such disputes were being classified as resolved "in favour of the applicant" in all cases where the applicant was "awarded anything, no matter how minor," and not necessarily the remedy that they were seeking (CameronRalph Navigator 2014, 112). After interviewing a number of past applicants, the review found some applicants who considered themselves to 
have substantively "lost" the dispute, and yet whose dispute was nonetheless classified as resolved in their favor.

Insert Table 2 around here

There have been major changes in the incidence of certain dispute outcomes over our five-year study period. Most significantly, as shown in Table 3, the proportion of disputes resolved by the FSP declined from 61 percent in 2010 to 35 percent in 2014. All other dispute outcomes have increased except for disputes discontinued by the applicant, which declined from 13 percent in 2010 to 6 percent in 2014. The proportion of disputes

- resolved by negotiation tripled relative to other outcomes from 5 percent in 2010 to 17 percent in 2014. The proportion of disputes resolved by conciliation nearly quadrupled from 4 percent in 2010 to 14 percent in 2014. Disputes found to be outside the FOS Terms of Reference increased from 17 percent in 2010 to 20 percent in 2014 .

\section{Length of the Dispute Resolution Process in FOS Financial Difficulty Disputes}

One of the major concerns about FOS as an avenue for seeking relief has been about the length of the dispute resolution process, and the effects of delay on applicants in financial hardship. The length of this process was a particular focus of the independent review of FOS in 2013 (CameronRalph Navigator 2014). Our findings in this subsection of the article indicate that the length of time taken to close a dispute has improved from 2013 onward. The average number of days taken to close an application went up from 91 in 2010 to 110 in 2011, dropping only slightly in 2012 before rising to 117 in 2013 and then falling to 98 days in 2014. The mean amount of time to close an application over the entire study period is 106 days, and the median amount of time is 73 days.

\section{Applicants in FOS Financial Difficulty Disputes}

In the context of financial difficulty disputes, FOS is primarily a dispute resolution forum for individuals, not companies. Between 2010 and 2014, 94 percent of applicants in these disputes were natural persons, with the remaining 6 percent comprising incorporated and unincorporated businesses.

Approximately 58 percent of applicants were male and 42 percent were female, 
and this gender distribution remained relatively constant over time. A small proportion of applicants - 2 percent-identified as Indigenous or Torres Strait Islander. The ages of the applicants - as shown in Table 4-demonstrate that FOS has been used primarily by middle-aged and older demographics. People aged under 30 composed only 6 percent of applicants over the study period, while 24 percent of applicants were aged between 41 and 50, and 35 percent were aged 51 and over.

Insert Table 4 around here

There have been some changes over time in the prevalence of particular age groups among the applicants. In particular, the number of applicants aged 51 and over declined markedly from 54 percent of all applicants in 2010 to 40 percent in 2014. Conversely, the proportion of applicants aged 31 to 40 has increased from 13 percent in 2010 to 21 percent in 2014, while applicants aged 41 to 50 have also increased from 27 percent to 31 percent.

There have also been some changes in the manner by which applicants find out about or are referred to FOS as an avenue for dispute resolution. As shown in Table 5, in 28 percent of financial difficulty disputes, the applicant already knew about FOS before registering their dispute. A further 12 percent of disputes were referred to FOS by a financial counselor. In only a very small proportion of disputes, the applicant found out about FOS from the FSP with which they were in dispute. This suggests that despite the incorporation of requirements for FSPs to inform consumers about their rights under the relevant EDR scheme into section 72 of the National Credit Code and also into industry codes of practice, consumers remain unlikely to bring an application to FOS solely on the basis of the information that is being provided to them under these requirements.

Insert Table 5 around here

The figures shown in Table 5 are the result of varying degrees of fluctuation in the sources through which applicants were referred to FOS over time. The proportion of disputes where the applicant already knew about FOS rose from 29 percent in 2010 to 34 percent in 2014, and is consistent with the findings of the independent review of FOS, which noted an increase in "widespread community recognition of the presence and role of Ombudsman schemes" (CameronRalph Navigator 2014, 72). During the same period, the proportion of applicants referred to FOS by services such as financial counselors or Legal Aid has declined, with referrals from Legal Aid in particular falling from 12 percent in 2010 to 6 percent in 2014. 
The final issue that we focused on in our analysis was the proportion of applicants who brought more than one financial difficulty dispute to FOS between 2010 and 2014. As shown in Table 6, the overwhelming majority-89 percent — of applicants lodged only one financial difficulty dispute with FOS during this period. Meanwhile, just 1 percent of applicants, or 168 applicants in total, registered 5 or more financial difficulty disputes with FOS, while 159 applicants registered 4 disputes during these five years.

Insert Table 6 around here

\section{Conclusion}

Over the short period since it commenced operations in 2008, FOS has played an important role in providing Australian consumers with an accessible avenue for seeking redress against FSPs. This role has been particularly important in the case of consumers experiencing financial hardship, for whom the courts are not a realistic option, and who require access to efficient mechanisms for resolving any disputes that may arise in relation to their credit provider's implementation of section 72 of the National Credit Code.

Our analysis of the data on financial difficulty disputes resolved by FOS provides insight into the efforts made by FOS to deal with a significant increase in its caseload in the aftermath of the global financial crisis. The decline in the number of days taken to close an application since 2013, as well as the general increase in the proportion of disputes resolved by negotiation and conciliation, is consistent with a shift toward greater involvement by FOS earlier in the dispute resolution process. The changes in the types of issues involved in these disputes also suggest that FSPs are making greater efforts to engage with consumers in financial hardship (although such a conclusion is slightly offset by the gradual increase in the number of applications involving a failure to respond to a request for assistance by the FSP). The data is most informative insofar as it sheds light on what dispute resolution by FOS actually involves - particularly by highlighting the importance of unmediated communication between the FSP and the applicant at the initial stage of the FOS process, and the relative infrequency with which FOS is required to impose a formal determination upon the parties in dispute.

Yet the data also contains a number of significant gaps that, in light of the importance of FOS in the context of financial hardship, need to be resolved by way of further empirical research. While we know that FOS caters primarily to middle-aged and older demographics, we know relatively little about the 
other characteristics and circumstances of the consumers using FOS to resolve financial difficulty disputes. Iain Ramsay and Toni Williams (2011) have suggested that since its establishment, the Financial Ombudsman Service in the United Kingdom has been used primarily by middle class and upper-middleclass consumers, raising questions about the extent to which a similar assessment may apply to ombudsman services in Australia. In a submission to the independent review of FOS in 2003, consumer organizations were concerned that vulnerable groups such as migrants from a non-Englishspeaking background or people with a mental illness face additional barriers to using such services (Consumer Credit Legal Centre [NSW] and Consumer - Action Law Centre 2013). In its final report, the independent review of FOS acknowledged the concern that financial services EDR "serves middle-class, educated consumers well, but proves to be a difficult process for less 'paperwork-capable' consumers" (CameronRalph Navigator 2014, 79-80). This concern is a serious one; as specified by the United Nations in its consumer protection guidelines, access to justice requires dispute resolution procedures to be "expeditious" and "fair," and to "take particular account of the needs of low-income consumers" (United Nations General Assembly 1985, clause 28). Yet it is impossible, based on the available data, to determine to what extent this concern applies to the group of consumers who are using FOS (and others who are unable to access its dispute resolution service).

Furthermore, as Shelley McGill $(2012,354)$ suggests, access to justice requires fair outcomes, not only fair processes: "[a]ccess and justice, although interrelated, have different objectives: access focuses on reducing barriers to use, and justice focuses on the substantive and procedural fairness of the resolution." Yet we also have little information - beyond broad outcome categories - about what arrangements are actually being made in over half of financial difficulty disputes that are resolved directly between the applicant and the FSP. All of this highlights a need for further research into EDR services such as FOS both in Australia and elsewhere, particularly with a focus on the experiences of applicants who have been through the dispute resolution process.

\section{References}

Access to Justice Advisory Committee. 1994. “Access to Justice: an Action Plan.” Report. Canberra: Commonwealth of Australia.

Ali, S. F. 2013. Consumer Financial Dispute Resolution in a Comparative Context: Principles, Systems and Practice. Cambridge: Cambridge University Press.

Australian Bankers' Association. 2013. Code of Banking Practice. Sydney: Author. 
Australian Securities and Investments Commission (ASIC). 2000. "Submission to the Senate Select Committee on Superannuation and Financial Services." Inquiry into Superannuation and Financial Services. Victoria: Author.

Australian Securities and Investments Commission (ASIC). 2008. "ASIC Approves New Complaints Scheme that Promotes Better Outcomes for Consumers and Industry." Media release, May 20. Victoria: Author.

Australian Securities and Investments Commission (ASIC). 2013. Regulatory Guide 139:

Approval and Oversight of External Dispute Resolution Schemes. http://download.asic.gov.au/media/1240742/rg139published-13-june-2013.pdf.

Banking and Financial Services Ombudsman Limited. 2004. "Review of the Banking and Financial Services Ombudsman Scheme." Background paper.

http://www.fos.org.au/custom/files/docs/background_paper_ bfso independent review.pdf.

Bolkus, N.1989. "National Banking Ombudsman Needed.” Media release, April 10.

CameronRalph Navigator. 2014. Report to a Board of Financial Ombudsman Service: 2013 Independent Review. Final report.

http://www.fos.org.au/custom/files/docs/independentreview-final-report-2014.pdf.

Commonwealth of Australia. 1997. Financial System Inquiry Final Report. http://fsi.treasury.gov.au/content/FinalReport.asp.

Commonwealth of Australia. 2001. Corporations Act 2001. http: / /www.comlaw.gov.au/Series/C2004A00818.

Commonwealth of Australia. 2009. National Consumer Credit Protection Act 2009. http://www.comlaw.gov.au/Series/C2009A00134.

Consumer Credit Legal Centre (New South Wales) and Consumer Action Law Centre. 2013. Independent Review of FOS. Joint submission. http: / / consumeraction.org.au/wpcontent/uploads/2013/10/Joint-consumer-submission-toIndependent-Review-of-FOS-October-2013.pdf.

Customer Owned Banking Association. 2014. Customer Owned Banking Code of Practice. http: / / www . customerownedbanking.asn.au/consumers / cobcop.

Financial Ombudsman Service (FOS). 2010a. "Dealing with Customers in Financial Difficulty: Small Business." The Circular 2. http://www.fos.org.au/publications/the-fos-circular/foscircular-issue-2-april-2010/dealing-with-customers-infinancial-difficulty-small-business.

Financial Ombudsman Service (FOS). 2010b. 2009-2010 Annual Review. Melbourne, Australia: Author.

This article is protected by copyright. All rights reserved. 
Financial Ombudsman Service (FOS). 2010c. "Terms of Reference."

http://www.fos.org.au/about-us/terms-of-reference.

Financial Ombudsman Service (FOS). 2011. 2010-11 Annual Review. Melbourne, Australia: Author.

Financial Ombudsman Service (FOS). 2012. 2011-2012 Annual Review. Melbourne, Australia: Author.

Financial Ombudsman Service (FOS). 2013a. 2012-2013 Annual Review. Melbourne, Australia: Author.

Financial Ombudsman Service (FOS). 2013b. "How FOS Approaches Financial Difficulty."

" The FOS Approach: Financial Difficulty Series. Melbourne, Australia: Author.

Financial Ombudsman Service (FOS). 2013c. "Our Power to Vary Regulated Credit Contracts.” The FOS Approach: Financial Difficulty Series. Melbourne, Australia: Author.

Financial Ombudsman Service (FOS). 2014. Annual Review 2013-14. Melbourne, Australia: Author.

Financial Ombudsman Service (FOS). 2015a. A Guide to Conciliation Conferences. http://www.fos.org.au/custom/files/docs/guide to concilia tion_conferences.pdf.

Financial Ombudsman Service (FOS). 2015b. New Dispute Resolution Process. http://www.fos.org.au/resolving-disputes/our-new-process.

Griffiths, T., and J. Mitchell. 2012. "Financial Ombudsman Service: Dr Jekyll or Mr Hyde?" Australian Insurance Law Bulletin 27 (9): 130-35.

James, R., and P. Morris. 2003. "The New Financial Ombudsman Service in the United Kingdom: Has the Second Generation Got it Right?" In International Perspectives on Consumers' Access to Justice, edited by C. E. F. Rickett and T. G. W. Telfer, 167-95. Cambridge: Cambridge University Press.

Malbon, J. 2012. "Small Amount Claims in the Consumer Marketplace: Lessons from Australia." In Middle Income Access to Justice, edited by M. Trebilcock, A. Duggan and L. Sossin, 328-51. Toronto: University of Toronto Press.

[AQ2]Malbon, J. 2013. "Responsible Lending, Unjust Terms and Hardship." In Consumer Law \& Policy in Australia \& New Zealand, edited by J. Malbon and L. Nottage, 24161. Annandale, New South Wales: Federation Press.

McGill, S. 2012. “Challenges in Small Claims Court Design: Does One Size Fit All?” In Middle Income Access to Justice, edited by M. Trebilcock, A. Duggan and L. Sossin, 352-82. Toronto: University of Toronto Press.

National Alternative Dispute Resolution Advisory Council (NADRAC). 2003. Dispute Resolution Terms. Paper.

http://www.ag.gov.au/LegalSystem/AlternateDisputeResoluti

This article is protected by copyright. All rights reserved. 
OTerms.PDF.

Nelthorpe, D., and K. Digney. 2011. “The Bulk Debt Negotiation Project.” Report. Victoria, Australia: West Heidelberg Community Legal Service.

O’Shea, P. 2006. “The Lion's Question Applied to Industry-Based Consumer Dispute Resolution Schemes." ADR Bulletin 8 (5): 83-91.

Pearce, C. 2007. "Breakthrough 2007: Address to the IFSA Annual Conference.” Speech presented at the IFSA Annual Conference, Brisbane, Australia, August 2.

Pearson, G. 2009. Financial Services Law and Compliance in Australia. Cambridge: = Cambridge University Press.

[AQ3]Productivity Commission. 2008. Review of Australia's Consumer Policy Framework. Report, vol. 2. Melbourne, Victoria, Australia: Commonwealth of Australia.

[AQ4]Ramsay, I. 2003. "Consumer Redress and Access to Justice.” In International Perspectives on Consumers' Access to Justice, edited by C. E. F. Rickett and T. G. W. Telfer, 17-45. Cambridge: Cambridge University Press.

Ramsay, I., and T. Williams. 2011. "The Crash that Launched a Thousand Fixes: Regulation of Consumer Credit After the Lending Revolution and the Credit Crunch." In Law Reform and Financial Markets, edited by K. Alexander and N. Moloney, 221-51. Cheltenham: Edward Elgar.

Schetzer, L. 2008. "Courting Debt: The Legal Needs of People Facing Civil Consumer Debt Problems." Report. Melbourne: Department of Justice.

Sourdin, T. 2012. Alternative Dispute Resolution, 4th ed. Pyrmont, New South Wales: Lawbook Co.

Trigg, P. 2006. "Choice of Funds_-FICS or the SCT? The Impact of Choice on Alternate Dispute Resolution.” Insurance Law Journal 17 (3): 205-36.

Waye, V., and V. Morabito. 2012. "Collective Forms of Consumer Redress: Financial Ombudsman Service Case Study.” Journal of Corporate Law Studies 12 (1): 1-32.

United Nations General Assembly. 1985. Guidelines for Consumer Protection. UN Doc $\mathrm{A} / \mathrm{Res} / 39 / 248$.

Paul Ali is an associate professor and a member of the Centre for Corporate Law and Securities Regulation, Melbourne Law School, The University of Melbourne.

Evgenia Bourova is the research fellow for the Financial Hardship Project, Melbourne Law School, The University of Melbourne.

Joseph Horbec is a research assistant for the Financial Hardship Project, Melbourne Law School, The University of Melbourne.

Ian Ramsay is the Harold Ford Professor of Commercial Law and director for the Centre for Corporate Law and Securities Regulation, Melbourne Law School, The University of Melbourne. 
Table 1. Disputes Received and Accepted by FOS from 2009 to 2014

\begin{tabular}{|llllll|}
\hline $\begin{array}{l}\text { Financial } \\
\text { Year }\end{array}$ & $\begin{array}{l}\text { Total } \\
\text { Disputes } \\
\text { Received }\end{array}$ & $\begin{array}{l}\text { Received } \\
\text { Financial } \\
\text { Difficulty } \\
\text { Disputes }\end{array}$ & $\begin{array}{l}\text { Accepted } \\
\text { Financial } \\
\text { Difficulty } \\
\text { Disputes }\end{array}$ & $\begin{array}{l}\text { Accepted } \\
\text { vs } \\
\text { Received }\end{array}$ & $\begin{array}{l}\text { Received } \\
\text { vs Total }\end{array}$ \\
2009 & 22,392 & $\mathbf{4 , 0 3 1}$ & 3,023 & $75.0 \%$ & $\mathbf{1 8 . 0 \%}$ \\
2010 & 23,790 & 2,648 & 1,986 & $75.0 \%$ & $11.1 \%$ \\
2011 & 30,283 & 6,102 & 4,577 & $75.0 \%$ & $20.1 \%$ \\
2012 & 36,099 & 8,659 & 6,626 & $76.5 \%$ & $24.0 \%$ \\
$2013 \bigcirc$ & 32,307 & 6,531 & 5,161 & $79.0 \%$ & $20.2 \%$ \\
2014 & 31,680 & 5,928 & 4,705 & $79.4 \%$ & $18.7 \%$ \\
\hline
\end{tabular}

Table 2. Outcome Types in Financial Difficulty Disputes

\begin{tabular}{|lll|}
\hline Outcome Type & All Observations & \% \\
Resolved by FSP & 12,503 & $53 \%$ \\
Outside Terms of Reference & 4,420 & $19 \%$ \\
Negotiation & 2,780 & $12 \%$ \\
Conciliation & 1,936 & $8 \%$ \\
Discontinued & 1,363 & $6 \%$ \\
Assessment & 393 & $2 \%$ \\
Decision in Favor of Applicant & 232 & $1 \%$ \\
Decision in Favor of FSP & 145 & $1 \%$ \\
FSP Offer/Action Confirmed & 31 & $0 \%$ \\
Total & $\mathbf{2 3 , 8 0 3}$ & $\mathbf{1 0 0 \%}$ \\
\hline
\end{tabular}

Table 3. Dispute Outcomes over Time

\begin{tabular}{|l|l|l|l|l|l|}
\hline Dispute Outcomes & $\mathbf{2 0 1 0}$ & $\mathbf{2 0 1 1}$ & $\mathbf{2 0 1 2}$ & $\mathbf{2 0 1 3}$ & $\mathbf{2 0 1 4}$ \\
\hline Resolved by FSP & 1,102 & 3,460 & 3,789 & 2,330 & 1,822 \\
& $(60.68 \%)$ & $(66.83 \%)$ & $(58.57 \%)$ & $(45.38 \%)$ & $(34.99 \%)$ \\
\hline Outside Terms of & 301 & 770 & 1,210 & 1,078 & 1,061 \\
Reference & $(16.57 \%)$ & $(14.87 \%)$ & $(18.70 \%)$ & $(21.00 \%)$ & $(20.38 \%)$ \\
\hline Negotiation & 97 & 195 & 780 & 806 & 902 \\
\hline & $(5.34 \%)$ & $(3.77 \%)$ & $(12.06 \%)$ & $(15.70 \%)$ & $(17.32 \%)$ \\
\hline Conciliation & 68 & 328 & 373 & 433 & 734 \\
& $(3.74 \%)$ & $(6.34 \%)$ & $(5.77 \%)$ & $(8.43 \%)$ & $(14.10 \%)$ \\
\hline Discontinued & 228 & 329 & 223 & 255 & 328 \\
& $(12.56 \%)$ & $(6.36 \%)$ & $(3.45 \%)$ & $(4.97 \%)$ & $(6.30 \%)$ \\
\hline
\end{tabular}




\begin{tabular}{|c|c|c|c|c|c|}
\hline Assessment & $\begin{array}{l}18 \\
(0.99 \%)\end{array}$ & $\begin{array}{l}83 \\
(1.60 \%)\end{array}$ & $\begin{array}{l}57 \\
(0.88 \%)\end{array}$ & $\begin{array}{l}111 \\
(2.16 \%)\end{array}$ & $\begin{array}{l}124 \\
(2.38 \%)\end{array}$ \\
\hline $\begin{array}{l}\text { Decision in Favor of } \\
\text { Applicant }\end{array}$ & $-(0.00 \%)$ & $3(0.06 \%)$ & $\begin{array}{l}15 \\
(0.23 \%)\end{array}$ & $\begin{array}{l}80 \\
(1.56 \%)\end{array}$ & $\begin{array}{l}134 \\
(2.57 \%)\end{array}$ \\
\hline $\begin{array}{l}\text { Decision in Favor of } \\
\text { FSP }\end{array}$ & $1(0.06 \%)$ & $6(0.12 \%)$ & $\begin{array}{l}17 \\
(0.26 \%)\end{array}$ & $\begin{array}{l}35 \\
(0.68 \%)\end{array}$ & $\begin{array}{l}86 \\
(1.65 \%)\end{array}$ \\
\hline $\begin{array}{l}\text { FSP Offer/Action } \\
\text { Confirmed }\end{array}$ & $1(0.06 \%)$ & $3(0.06 \%)$ & $\begin{array}{l}5 \\
(0.08 \%)\end{array}$ & $6(0.12 \%)$ & $\begin{array}{l}16 \\
(0.31 \%)\end{array}$ \\
\hline Total & 1,816 & 5,177 & 6,469 & 5,134 & 5,207 \\
\hline
\end{tabular}

Table 4. Ages of Applicants

\begin{tabular}{|l|l|l|}
\hline $\begin{array}{l}\text { Observed Age } \\
\text { Ranges }\end{array}$ & Count & $\%$ \\
\hline 20 or less & 146 & 1 \\
\hline $21-30$ & 1,351 & 5 \\
\hline $31-40$ & 3,595 & 15 \\
\hline $41-50$ & 6,003 & 24 \\
\hline 51 or more & 8,667 & 35 \\
\hline Unknown & 4,861 & 20 \\
\hline Total & $\mathbf{2 4 , 6 2 3}$ & $\mathbf{1 0 0}$ \\
\hline
\end{tabular}

Table 5. Referral to FOS[AQ1]

\begin{tabular}{|l|l|l|}
\hline Referred by & Count & $\%$ \\
\hline Already knew about FOS & 6,913 & 28 \\
\hline Not provided & 4,124 & 17 \\
\hline Financial counselor & 3,059 & 12 \\
\hline Internet & 2,044 & 8 \\
\hline Legal Aid/free legal service & 1,989 & 8 \\
\hline Family/friends/colleague (word of mouth) & 1,615 & 7 \\
\hline Solicitor/legal professional & 1,443 & 6 \\
\hline FSPI have a dispute with & 678 & 3 \\
\hline $\begin{array}{l}\text { Another dispute resolution scheme (e.g., } \\
\text { SCT) }\end{array}$ & 569 & 2 \\
\hline $\begin{array}{l}\text { Community center/consumer } \\
\text { representative }\end{array}$ & 570 & 2 \\
\hline Government agency (e.g., ACC, ASIC, & 490 & 2 \\
\hline
\end{tabular}

This article is protected by copyright. All rights reserved. 


\begin{tabular}{|l|l|l|}
\hline APRA) & & \\
\hline Financial planner & 290 & 1 \\
\hline Charity/church organization & 273 & 1 \\
\hline Media (e.g., newspaper, magazine) & 167 & 1 \\
\hline Phone directory & 155 & 1 \\
\hline Member of Parliament & 79 & 0 \\
\hline Newspaper/magazines & 42 & 0 \\
\hline Event/trade fair/presentation & 42 & 0 \\
\hline Industry association (e.g., ABA, FPA, & 41 & 0 \\
\hline IFSA) & & \\
\hline Welfare/migrant service & 34 & 0 \\
\hline Unknown & 6 & 0 \\
\hline Total & $\mathbf{2 4 , 6 2 3}$ & $\mathbf{1 0 0}$ \\
\hline
\end{tabular}

Table 6. Number of Financial Difficulty Disputes per Applicant

\begin{tabular}{|l|l|l|}
\hline & $\begin{array}{l}\text { Number of } \\
\text { Applicants }\end{array}$ & $\%$ \\
\hline Applicants who lodged 1 dispute & 18,659 & 89 \\
\hline Applicants who lodged 2 disputes & 1,513 & 7 \\
\hline Applicants who lodged 3 disputes & 419 & 2 \\
\hline Applicants who lodged 4 disputes & 159 & 1 \\
\hline Applicants who lodged 5 or more disputes & 168 & 1 \\
\hline Total & $\mathbf{2 0 , 9 1 7}$ & $\mathbf{1 0 0}$ \\
\hline
\end{tabular}

This article is protected by copyright. All rights reserved. 


\section{QUERIES}

AQ1 Table 5: One row is "Media (e.g., newspaper/magazine)" and another is "Newspapers/magazines"; should these be merged? If they are distinct, can you please clarify how?

AQ2 Malbon (2013) is not cited in the text. Please cite or delete.

AQ3 Productivity Commission (2008) is not cited in the text. Please cite or delete.

AQ4 Ramsay (2003) is not cited in the text. Please cite or delete.

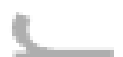

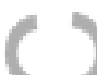

$\infty$

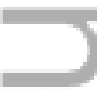
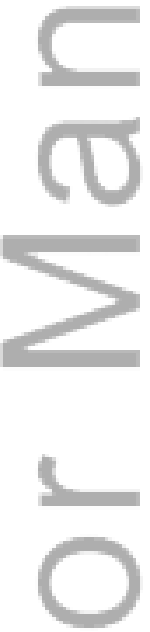

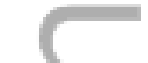

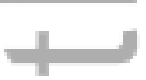

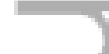

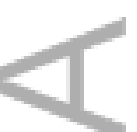

This article is protected by copyright. All rights reserved. 


\section{University Library}

\section{- M M N E R VA A gateway to Melbourne's research publications}

Minerva Access is the Institutional Repository of The University of Melbourne

Author/s:

Ali, P;Bourova, E;Horbec, J;Ramsay, I

Title:

Australia's Financial Ombudsman Service: An Analysis of Its Role in the Resolution of Financial Hardship Disputes

Date:

2016-12-01

Citation:

Ali, P., Bourova, E., Horbec, J. \& Ramsay, I. (2016). Australia's Financial Ombudsman Service: An Analysis of Its Role in the Resolution of Financial Hardship Disputes. CONFLICT RESOLUTION QUARTERLY, 34 (2), pp.163-188. https://doi.org/10.1002/crq.21187.

Persistent Link:

http://hdl.handle.net/11343/291881 